\section{Memoirs of a septuagenarian}

\section{Roy Porter}

The Diary of William Harvey: The Imaginary Journal of the Physician Who Revolutionized Medicine. By Jean Hamburger. Rutgers University Press: 1992. Pp. 255. \$35 (hbk), \$14.95 (pbk).

Wro knows how many readers have read The Diary of a Surgeon, published in 1937, believing it to be the journal of the young medic, William Knyveton, and a reliable account of the horrors of eighteenth-century practice, without the slightest suspicion it was a hoax played on them by that wily medical writer, Ernest Gray? Any such temptation to tease has been quite wisely resisted by the distinguished French medical researcher Jean Hamburger in his overtly fictional reconstruction of the mental musings of Britain's most eminent physician.

Even so, this touchingly written and beautifully translated volume is still not what one might expect. The natural subject-matter for a fictional diary would have been a day-by-day account leading from Harvey's student days up to the thrilling events of the $1620 \mathrm{~s}$ when he convinced himself that the Ancients had quite misunderstood the function of the heart and had fabricated a cardiac anatomy that was in crucial aspects utterly fanciful. Bravely challenging Classical dogma, Harvey had then undertaken the monumental serics of experiments that demonstrated the circulation of the blood - even if, to Harvey's intense irritation, notable physicians such as Riolan in France insisted on upholding the ex cathedra judgements of Galen against the experience of the eyes. A blow-by-blow account of the great breakthrough would have proved an exhilarating read, offering Hamburger a golden opportunity to rethink the dialectic of hypothesis and experiment leading to De Motu Cordis (1628), and so perhaps to gloss modern conceptions of creativity and what Thomas Kuhn calls the "structure of scientific revolutions".

This is not what Hamburger has attempted. Rather, opening in 1647, he has given us Harvey in his seventies, gout-ridden and sometimes crotchety; and he has imagined not so much a diary but rather the memoirs of a man of full years, still obliged to defend his discovery, and not just against the Antidiluvians but also against those new men such as his crony Thomas Hobbes and also Renć Descartes, who were putting it to use in mechanical philosophies that aroused deep suspicion. Harvey's child was breaking away from its father.
It is a subtle choice. It gives Hamburger the opportunity to depict Harvey as a mature thinker, complete with the philosophy of organic life more evident in later embryological writings such as De Generatione than in his studies of the heart. Hamburger's is a respectful Harvey, who can cherish the wisdom of Aristotelian teleology, while repudiating the medical old guard's Galen-worship. It is a Harvey who has honed natural philosophical maxims of his own: "doubt is the most important quality a scientist can possess".

By choosing the septuagenarian, Hamburger can explore Harvey-the-man no less than Harvey-the-researcher. For many years King Charles I's personal physician and growing politically more crusty with age, the Royalist Harvey lamented the Great Rebellion. The year 1647 found the country in limbo, the Civil War over, the situation of King, Army and Parliament unresolved. Through a clever device, the great shift in the three years of diary here 'recorded' is not some event in Hamburger's hero's life per se, but Harvey's response to the unforeseen, unthinkable but, with the aid of hindsight, inexorable via crucis of the king towards the scaffold in January 1649: an event that reduces the normally garrulous physician to pathetic nearsilence: "2 February 1649. The King is dead. His death is murder and, even though he remained in the background, I hold Cromwell to be his murderer." It is a neat irony that Harvey, who had earlier dethroned the heart, reducing it from being the very monarch of life into a mere muscle, a mechanical pump, should nevertheless have deplored the parallel revolution within the body politic.

Hamburger has a flair for evoking the strange pageant of Baroque Europe, half-old, half-new, one foot still in the camp of magic and the occult, the other in the world of Galileo and the new philosophy: the Rosicrucian Robert Fludd, Gassendi, Mersenne, John Evelyn and John Milton (as politician not poet) all flit in and out of the pages. There is a memorable vignette of the courtier Sir Kenelm Digby touting mountebank-like his unique "powder of sympathy" that supposedly healed wounds by sympathetic magic, while sustaining his beautiful wife Venetia only on capons fed on viper flesh, hoping to preserve her youth. Hamburger's reconstruction of Harvey's life and mind combines accuracy with an allowable imaginative licence. Here and there, it is a

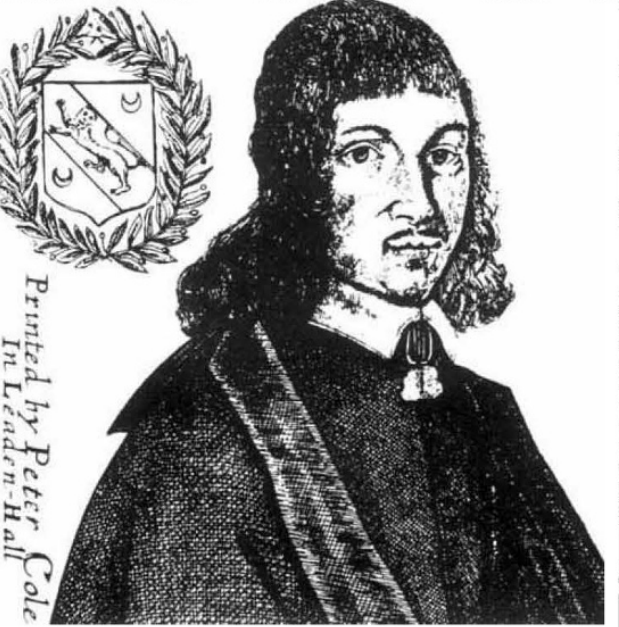

1616, the year Harvey first lectured on the irculation of the blood, Nicholas Culpeper, opular figurehead of 'aiternative' medicine and Harvey's polar opposite, was born. With his unauthorized translation of the London ispensatory, Culpeper became the enemy of physicians, and in 1652, he wrote his amous herbal The English Physician. The yths surrounding his life are now explored by lav Thulesius in Nicholas Culpeper: Physician and Astrologer. Macmillan, £40. bit too knowing ("... this epoch is creative. Everything will progress very quickly from now on"). Yet in general, Hamburger admirably catches the solemn, melancholy mood of a greybeard oppressed by the vanity of all-talk no-action intellectuals such as the despised courtier Francis Bacon, who, quipped Harvey, did science like a Lord Chancellor. Harvey was committed to belief in scientific progress - there lay the only escape from the bloodshed and butchery that had attended all his days. Yet even towering medical advance led the old man's mind back to an inescapable anatomy of melancholy: "my eyes will never forget Fabricius' Anatomy Theatre; at the bottom of the five circular tiers, on the central dissecting table, a corpse, the anatomical model, showed us all what becomes of a man at the end of his earthly history".

This is a jeu d'esprit. It is also a splendid attempt to probe beneath the skin of a figure, the sheer range of whose biomedical achievements is all too rarely appreciated. For Hamburger's Harvey, pursuit of truth was the pole star, the equivalent to the sexual drive in others. Avoiding the pitfall of twee archaic language, The Diary of William Harvey is also, as the extracts show, an enchanting read. Hamburger's death earlier this year highlights the poignancy of his moving book.

Roy Porter is at the Wellcome Institute for the History of Medicine, 183 Euston Road. London NW1 2BN, UK.

NATURE · VOL 360 • 26 NOVEMBER 1992 